\title{
Capital Flight, Hard Mineral Resources Exports and Political Governance Crisis in the Central African Republic: How Far We have Learned?
}

\section{Thales Pacific Yapatake Kossele ( $\nabla$ yapatakethales@ceredec.org )} Oxford University Press

\section{Research}

Keywords: Capital flight, hard mineral resources, Political Governance crisis, Multiple Correspondence Analysis, ARDL, CAR

Posted Date: October 9th, 2020

DOI: https://doi.org/10.21203/rs.3.rs-88690/v1

License: @ (i) This work is licensed under a Creative Commons Attribution 4.0 International License. Read Full License 


\section{Abstract}

The Autoregressive Distributed Lag (ARDL) approach to cointegration is applied to examine the role of political governance crisis in the relationship between hard mineral resources exports particularly diamond, and gold and Capital flight in the Central African Republic over the period of 1978-2010. The results of shortrun show that official development assistance, gross national expenditures have a negative and significant impact on capital flight while the interaction of political governance crisis and hard mineral resources, GDP per capita have a positive and significant effect with capital flight. Moreover, governance crisis, exports of hard mineral resources has a negative and insignificant impact on capital flight. The results of the long run show a negative and significant effect on governance crisis, official development assistance and gross of national expenditures. The interaction term between hard mineral resources and GDP growth have a positive and significant effect on capital flight. However, export of hard mineral resources exhibits a positive but insignificant effect on capital flight. Without strong action to stop and promote political governance stability and the implementation of appropriate reforms at institutional level in CAR's hard minerals resources sector, success in the fight against capital flight is unlikely.

\section{Introduction}

Capital flight has become an increasing source of concern for political actors in developed countries, such as the Central African Republic (CAR), where there are insufficient resources to finance growth. According to Ajayi (1997), capital flight has been attributed to slow economic growth and persistent balance of payment deficits in most developing countries. Indeed, high capital flight rates pose significant challenges to the mobilization of domestic resources to sustain investment and development in Africa (Fofack and Ndikumana, 2009 and 2010).With respect to Boyce and Ndikumana (2012), CAR is ranked 26th among the sub-Saharan African countries with the highest capital flight rates in the 1970-2010 period. The total real capital and total real capital flight per capita were estimated at $\$ 2.7$ and 619.2 billion 2010 versus Cameroon estimated at $\$ 20$ and $\$ 1020$ billion2010 $\$$. While the volume is low compared to other African countries such as Cameroon, careful attention should be given to the fact that it poses a comparatively heavier burden (Nkurunziza, 2015) and that the country still faces major problems in terms of growth, including many off-track sustainable development goals (SDGs).The country's GDP per capita was USD 489.87 from 1960 to 2017, which is equivalent to $3 \%$ of the world's average GDP per capita and is considerably lower than that of other fragile countries in sub-Saharan Africa. In fact, its population continues to suffer from severe poverty $(76 \%$ of the central African citizens live of less than US\$ 1.0 a day).In addition, the political governance crisis that the country has experienced since its independence has exacerbated the situation and created tensions over hard mineral resources, leading to poor governance of natural resources. As long as bad governance has been reported as an significant determinant of capital flight through trade mis-invoicing, corruption, tax evasion, rent-seeking (Le Billon, 2011; Ljungberg and Friedl, 2014), a strong link between natural resources and capital flight may be identified through illicit offshore transfer and subsequent deposit of illicit funds in tax havens. (Asongu and Odhiambo, 2019).

While the literature on capital flight has recently centred on the institutional climate (Gankou et al. 2016), as well as the effect of governance on capital flight (Asongu and Nwachukwu, 2017, Yapatake and Ngaba, 2019), a broad body of literature that explored the relation between abundance of resources and conflict (Le Billon, 
2011; Ross et al., 2013) has provided two contradictory findings. Some researchers described natural resources as a blessing (Arezki and Van der Ploeg, 2007) and others as a curse (Egorov et al., 2009; Polterovich et al., 2007; Kolstad, 2009). In addition, the capital flight literature has also highlighted the role of political risk and political governance crisis as factors in driving capital flight (Yapatake and Njong, 2020; Lensink et al., 2000; Le and Zak, 2006). Furthermore, there is evidence in the literature that African countries with rich natural resources seem to be prominently at the top of the list of countries with high capital flight, and the correlation seems stronger for oil than other resources such as hard mineral resources (Ndikumana et al. 2016). Nevertheless, the increasing number of work on governance (Kangoye; 2013; Musila and Sigué, 2010) and capital flight (Mpenya et al. 2015; Ndiaye and Siri, 2016) lack of literature illustrates the role of the political governance crisis in the relationship between capital flight and hard mineral resources.

The Central African Republic is regarded as a resource-dependent nation and an insecure democratic stability region marked by civil wars, protests, coups d'états, inter-confessional conflicts, the continuing involvement of foreign forces that tend to exacerbate the capital flight. Studies also report that maladministrated resources create grievances and increase probability, duration and severity of conflicts (Valenzuela, 2020; Vogel and Havenith, 2017, Aspinall, 2007). With an insecure political climate and a global governance crisis, countries rich in natural resources were faced with badly defined land rights, fragmented economies, poorly structured political institutions, instability and insecurity. These conditions offer the best incentives for corporations, policymakers and senior officials to seek rent that diverts money from more efficient economic projects (Auty, 2004; Le and Zak, 2006).

In interpretation of the political governance crisis as one of the dimensions of poor governance, this study empirically examines the role of the political governance crisis in the relationship between capital flight and hard mineral resources in the CAR due to the fact that CAR is not spared from the problem of capital flight and the fight against capital flight, which could therefore be an important catalyst of the country's development. As far as I know, no substantial research has been carried out on capital flight, hard mineral resources and the CAR governance crisis in particular. One wonders, though, if capital flight is not a major issue for the Central African Republic

The uniqueness of this study is therefore to provide a detailed evaluation of political governance through an index construct that specifically takes into account changes in constitution and government, tensions, violence and politically motivated, as well as political-military crises, as a factor leading to the variance of capital flight in hard mineral resources.

\section{Literature Review}

\subsection{Hard mineral resources and Political governance crisis in the Central African Republic}

The CAR is endowed with rich natural resources such as diamond, gold, uranium, iron, and tin, copper and nickel (see Fig. 1). It is from 1920 that mining prospects were undertaken, in particular by the Equatorial Company of the Mines in the Center and the East of the country.A law of January 17, 1961, gave the right to Central Africans to open their small mines for gold and diamonds. Mainly artisanal workers carry out the 
Central Africa Republic's gold and diamond production. In terms of rough diamond production volume, Central Africa Republic ranked 14th in the world, and in terms of value, it ranked 12th as of 2010. By the end of Bokassa's rule in 1979, production fluctuated at around 290,000 carats per year. The diamond sector, earning the country respectively $\$ 52.3$ million and $\$ 49.3$ million in 2009 , or $42.2 \%$ and $39.8 \%$ of the country's total export value.Export and import statistics show that about $\$ 5.6$ million worth of mineral commodities were exported to the USA in 2010. Nearly $\$ 3.3$ million of these exports were of rough diamonds. According to the latest data of the Kimberley Process available for the Central African Republic, 365,916 carats of Central African diamonds produced in 2012, worth $\$ 62$ million. That same year, 371,916 carats were exported from the country in 2016 and mining sector in total accounted for 7\% of GDP in 2007 and fiscal revenues from the sector came to $9 \%$ and $11 \%$ of the State's total fiscal revenues in 2009 and 2010 respectively.

Gold is the country's second-largest mineral resource behind the diamond. This makes the Central African Republic, an important destination for any serious investor in the gold production sector. After the country gained its independence, there were efforts to start large-scale gold mining but persistent civil strife slowed down the growth of the country in the mining sector. Official gold production figures have risen from an average $20 \mathrm{~kg}$ per year in the 2004-2007 periods to an average $60 \mathrm{~kg}$ in 2008-2011. Central African Republic's Gold Production was reported at $60 \mathrm{~kg}$ in Dec 2015. This stayed constant from the previous number of $60 \mathrm{~kg}$ for December 2014. The highest-level history of gold production reached in 1988 at 382.00 $\mathrm{Kg}$, the lowest level in 1965 at $0.62 \mathrm{Kg}$.

Concerning the governance crisis, since independence in 1960, the country is characterized by an unstable political governance crisis. Except for the presidential elections between Kolingba and Ange-Félix Patassé, in 1993-1994 and the election of Faustin Archange Touadéra in 2016, coups and mutinies have rocked the daily life of the country.

The causes of the political governance crisis in the CAR are diverse and varied. Military coups, army mutinies, and extended labor disputes, combined with poor macroeconomic management and weak governance, have led to the deterioration of the political environment as well as economic and social performance. In addition to that, road blockers or Zaraguinas, which are located mainly in the West, the North-west, and the Northeast and in the Center of the country, have seriously contributed to the degradation of the internal security. Another possible cause of the political governance crisis is linked to the extreme poverty that prevails throughout CAR, especially the high socio-economic disparities between the north and other regions. As well as the geopolitical position with other countries in particular Chad, Sudan, the Democratic Republic of Congo has contributed partly to the destabilization of the country.

The weakness of the national defense is also a factor of political governance crisis and the limited resources of Central African Army adding to those natural resources rent-seeking. Besides that, the country is characterized frequents changes in the constitution and government changes which are always conditioned by abrupt changes in executive power. The country was also shaken by military crisis, punctuated by coups d'état, mutinies, civil wars, interethnic and confessional conflicts, rebellions, regional instability as well as French support for dictatorial regimes. About 60 percent of the territory remains controlled by armed groups and the country still experienced an upsurge in clashes between armed groups, competing for territory, and access to resources. Each episode of violence brings new civilian casualties and additional

Page $4 / 23$ 
displacement.Tensions, violence, and protestations politically motivated have shared the political history of the country and have created deeper divisions within the population, leading to an increase in the likelihood of continued violence based on identity.

The capital flight literature has explored some causes of capital flight including GDP growth, political instability, corruption, institutional quality (Bredino et al., 2018; Yapatake and Ngaba, 2019; Gankou et al., 2016). Previous research on the connection between natural resource and capital flight is not limited to a study by (Demachi, 2013; Arezki et al., 2014; Kwaramba et al., 2016). In addition to that, the study conducted by Ndikumana and Sarr (2019) found high natural resource rents are associated with high capital flight and the quality of institutions does not mitigate this link. This means also that a significant amount of rentseeking takes place in resource economies, possibly fuelling capital flight.

In light of the objective, the study uses an index developed by us in order to highlight country peculiarities with regard to capital flight and hard mineral resources in the context of a political governance crisis. Several proposed effects of hard mineral resources and explanatory variables for capital flight coincide. The implication is that there should exist an observable correlation between the interaction of hard mineral resources and political governance crisis in relation to the capital flight considering the political governance crisis as the main channel by which this correlation occurs. The construction of the index is motivated by the fact that the Central African Republic has experienced an unstable political governance crisis which however has not been studied in relation to hard mineral resources and capital flight.

\subsection{Capital Flight and Natural Resources: Overview of the Transmission Mechanisms}

Numerous studies have looked at the capital flight determinants. (Ndikumana, 2012; Lonescu, 2013) have considered low investment in infrastructure, poor rule of law, budgets deficits and foreign borrowing as drivers of capital flight. Several studies have also outlined corruption, administrative efficiency, tax revenue collection, export misinvoicing, export mispricing (Ndikumana and Boyce, 2003; DeBoyrie, 2011; Mpenya et al., 2016; Ljungberg and Friedl, 2014). Specifically, by using exports as total share of total exports as proxy of natural resources, Ondo and Taylor (2012) find natural resources are directly related to the flight of natural capital. There was also an emphasis on the effect of political instability and poor governance in the induction of capital flight (Ramiandrisoa and Rakotomanana, 2016; Ndiaye and Siri; 2016). In order to discuss the relationship between capital flight, hard mineral exports and the CAR political governance crisis, we operationalized the concept of capital flight and hard mineral resources exports and political governance crisis by constructing a three-pronged flow chart.

Throughout the first phase of capital and natural resources, Boyce and Ndikumana (2012) clearly show that the sudden rise of capital flight in sub-Saharan African countries are correlated with a resource extraction growth during the pre-crisis period particularly in the main oil-producing countries. In particular, given that the CAR is well endowed with natural resources, a better understanding of this aspect is based on the effect of capital flight on the country's hard mineral revenues.

In the context of the CAR, where hard mineral resources are mined almost exclusively by craft miners and diamond workers, there is a high risk of corruption and a heightened impact of capital flight, notably through 
illicit exploitation and export smuggling, given the large number of informal operators. In addition, the capital flight in hard mineral sector is basically illustrated by the high value / weight ratio and the relative ease with which they can be produced, resulting in contraband, trade misinvoicing, corruption, illicit mining, tax base reduction depriving the country of significant amounts of revenues.

As regards the second aspect, the link between capital flight and the political governance crisis can be examined from the point of view of political risk as a determinant of capital flight. Boyce and Ndikumana (2012) have shown that bad governance due to abuse of political power is likely to be correlated to capital flight. Furthermore (Gibson and Tsakalotos, 1993; Ndikumana et.al, 2015; Davies, 2008 and Fatehi, 1994) showed that political risk and a weakening market climate were significant determinants of capital flight through damages and asset loss. Our CAR focus has enabled us to notice that the country is marked by an on-going political turmoil due to civil wars, coup d'états, minuties, changes in government, constitutional reforms that weaken the foundations of stability in democratic governance (Yapatake Kossele and Shan, 2018).

Provided the above-mentioned investors' reaction to the country's political events by moving resources to environments with lower investment risks (Hermes and Lensink, 2001; Le and Zak, 2006). Several scholars have also suggested in the third aspect on the natural resources and political stability issue that countries with an surplus of exportable point-source natural resources ( e.g. crude, natural gas, copper) are more likely to be ruled by oppressive regimes (Ross, 2001; Wantchekon ,2002). However, it could quickly suffer from economic stagnation (Bova et al., 2018) and is frequently driven by violence and political uncertainty (Ong'ayo, 2008; Williams and Le Billon, 2017). Supporting a foreign law that encourages rulers and greedy politicians to assume legally legitimate property transactions leads to irresponsible administration, natural resource mismanagement, tax haven, and poverty in many African countries such as the CAR.

In the context of the study's purpose, the relations between capital flight, hard mineral resources and political governance crisis can be explained from the viewpoint of how the political governance crisis affects capital flight movements in the diamond sector.

Figure 3 shows the connection between capital flight and hard mineral resources; the connection between diamond exports and the crisis of political governance; and finally the interaction between hard mineral resources exports and the crisis of political governance in relation to capital flight. Considering the role of the political governance crisis in the relationship between capital flight and hard mineral wealth, the framework may be formed by growing instability, which would drive investors to take their investments somewhere else. The political governance crisis may lead to an over-estimate or under-estimate of the invoice, as well as the price of commercial transactions involving natural resources, the distortion of the amount of transactions making it difficult for the invoice sent to customs to represent the real cost of the transactions. This statement should be especially verifiable in the CAR as a consequence of the political governance turmoil that the country has been going through continuously since its independence in 1960.

\section{Methodology}


The empirical methodology of this article applies the ARDL bounds test as proposed by Pesaran and and Smith (2001) to investigate the long- and short-run impacts of the selected variables on capital flight in the CAR over the period of 1978-2010. Therefore, the empirical methodology follows the next steps: First, checking for the unit root using the Augmented Dickey-Fuller (ADF) and Philips Perron tests for the selected variables. Second, based on the empirical analysis of stationarity, we will apply the ARDL bounds test for cointegration in the presence of structural breaks to capture the effect of hard mineral resources and political governance crisis and other variables on capital flight.

One of the reasons for preferring the ARDL is its applicability irrespective of whether the underlying regressors are purely or mutually cointegrated. Besides, endogeneity problems are addressed in this technique. According to (Pesaran and Shin, 1999), modeling the ARDL with the appropriate lags will correct for both serial correlation and endogeneity problems. Jalil et al (2013) argue that endogeneity is less of a problem if the estimated ARDL model is free of serial correlation. In this approach, all the variables are assumed to be endogenous and the long run and short-run parameters of the model are estimated simultaneously (Khan et al, 2005). Moreover, using the ARDL approach is more robust and performs better for small sample sizes than other cointegration techniques. The data of capital flight is obtained from Boyce and Ndikumana (2012). Hard mineral resources data are collected from the Central African Republic Bureau of statistics. Official development assistance, growth domestic product per capita, the gross national expenditures are collected from world development indicators. The political governance crisis index is constructed through the method of Multiple Correspondence Analysis (MCA) using three indicators, such as changes in constitution and government, Tensions, violence, and protest politically motivated as well as Politico-militaries Crises. The three indicators are built focusing on Central's African Characteristics, history and judicial and political cycles. The construction of the indicator is presented in Table 1. The three indicators are constructed based on the information from National Administrative authorities and online documentation. Changes in constitution takes the value 1 each time there is a constitution modification, 0 otherwise while change in government takes the value 1 each time a new prime minister is at end of his duty or the post is vacant (period of government instability) and 0 each time a new Prime Minister is appointed (period of government stability). Tensions, violence, and protest politically motivated indicator takes the value 1 each time there is tension, violence, protest, 0 otherwise. Politico-military crisis indicator, our dummy variable takes the value each time there is successful coup d'états, munities, and civil war, 0 otherwise. 
Table 1

Governance Crisis Index Construction

Changes in constitution and government of Central African Republic indicator from 1978-2010

Constitutions Changes

Governance

crisis

- Constitutional Act on the provisional organization of public authorities (21 September

1979: 1

1979)

- Ordnance $N^{\circ} 79 / 017$ authorizing the creation of political parties in the Central African

Republic (October 26, 1979)

- Constitution of February 5, 1981 (second Republic)

1981: 1

- Constitutional Act $N^{\circ} 1$ (1st September 1981)

- Ordnance No. 81/001 (September 1, 1981)

- Constitutional Act $N^{\circ} 2$ (September 22, 1981)

- Constitutional Act No. 1 of 21 September 1985 on the dissolution of the Military

1985: 1

Committee of National recovery and establishing the office of president of the Republic,

Head of state and government.

- Constitutional Act No 2 of 21 September 1985 concerning the provisional organization of the public authorities.

- constitution of 26 November 1986 (Third Republic)

1986: 1

- Constitutional Act N¹ (March 15, 2003)

2003:1

- Constitutional Act $\mathrm{N}^{\circ} 2$ concerning the provisional organization of state powers (March

$15,2003)$

- Constitution of December 27, 2004 (Fifth Republic): ratified by the electorate in a referendum held on 5 December 2004 and was promulgated by Decree no 04-392, of

2004: 1 December 2004 and was amended once in 2010. 


\begin{tabular}{|c|c|c|c|}
\hline \multicolumn{4}{|c|}{ Government changes } \\
\hline Primes ministers & $\begin{array}{l}\text { Enter on } \\
\text { Duty }\end{array}$ & $\begin{array}{l}\text { End of } \\
\text { duty }\end{array}$ & Government crisis \\
\hline Henry Maidou & $\begin{array}{l}14 \mathrm{Jul} \\
1978\end{array}$ & $\begin{array}{l}26 \text { Sept } \\
1979\end{array}$ & 1979: 1 \\
\hline $\begin{array}{l}\text { Bernard } \\
\text { Ayandho }\end{array}$ & $\begin{array}{l}26 \text { Sept } \\
1979\end{array}$ & $\begin{array}{l}22 \text { Aug } \\
1980\end{array}$ & 1980:1 \\
\hline $\begin{array}{l}\text { Jean Pierre } \\
\text { Lebouder }\end{array}$ & $\begin{array}{l}12 \mathrm{Nov} \\
1980\end{array}$ & $\begin{array}{l}4 \mathrm{Apr} \\
1981\end{array}$ & $1981: 1$ \\
\hline $\begin{array}{l}\text { Simon Narcisse } \\
\text { Bozanga }\end{array}$ & $\begin{array}{l}4 \mathrm{Apr} \\
1981\end{array}$ & $\begin{array}{l}1 \text { Sept } \\
1981\end{array}$ & $\begin{array}{l}\text { 1981:1; 1982: 1; 1983:1; 1984: 1; 1985:1; 1986:1; 1987: } 1 \text {; } \\
\text { 1988:1; 1989: 1; 1990: } 1 \text {; 1991:1 }\end{array}$ \\
\hline Edouard Frank & $\begin{array}{l}15 \mathrm{Mar} \\
1991\end{array}$ & $\begin{array}{l}4 \mathrm{Dec} \\
1992\end{array}$ & 1992: 1 \\
\hline $\begin{array}{l}\text { Timothée } \\
\text { Malendoma }\end{array}$ & $\begin{array}{l}4 \text { Dec } \\
1992\end{array}$ & $\begin{array}{l}26 \mathrm{Feb} \\
1993\end{array}$ & 1993: 1 \\
\hline $\begin{array}{l}\text { Enoch Dérant- } \\
\text { Lakoué }\end{array}$ & $\begin{array}{l}26 \text { Feb } \\
1993\end{array}$ & $\begin{array}{l}25 \text { Oct } \\
1993\end{array}$ & 1993: 1 \\
\hline $\begin{array}{l}\text { Jean Luc } \\
\text { Mandaba }\end{array}$ & $\begin{array}{l}25 \text { Oct } \\
1993\end{array}$ & $\begin{array}{l}12 \mathrm{Apr} \\
1995\end{array}$ & 1995: 1 \\
\hline $\begin{array}{l}\text { Gabriel } \\
\text { Koyambounou }\end{array}$ & $\begin{array}{l}12 \mathrm{Apr} \\
1995\end{array}$ & $\begin{array}{l}6 \text { Jun } \\
1996\end{array}$ & 1996:1 \\
\hline $\begin{array}{l}\text { Jean-Paul } \\
\text { Ngoupandé }\end{array}$ & $\begin{array}{l}6 \text { Jun } \\
1996\end{array}$ & $\begin{array}{l}30 \text { Jan } \\
1997\end{array}$ & 1997: 1 \\
\hline $\begin{array}{l}\text { Michel Gbézéra- } \\
\text { Bria }\end{array}$ & $\begin{array}{l}30 \text { Jan } \\
1997\end{array}$ & $\begin{array}{l}\text { 1er Feb } \\
1999\end{array}$ & 1999: 1 \\
\hline $\begin{array}{l}\text { Anicet-Georges } \\
\text { Dologuélé }\end{array}$ & $\begin{array}{l}1 \text { Feb } \\
1999\end{array}$ & $\begin{array}{l}1^{\mathrm{er}} \mathrm{Apr} \\
2001\end{array}$ & 2001: 1 \\
\hline Martin Ziguélé & $\begin{array}{l}1^{\text {er }} \mathrm{Apr} \\
2001\end{array}$ & $\begin{array}{l}15 \mathrm{Mar} \\
2003\end{array}$ & 2003: 1 \\
\hline Abel Goumba & $\begin{array}{l}23 \mathrm{Mar} \\
20003\end{array}$ & $\begin{array}{l}12 \mathrm{Dec} \\
2003\end{array}$ & 2003: 1 \\
\hline $\begin{array}{l}\text { Celestin } \\
\text { Gaombalet }\end{array}$ & $\begin{array}{l}12 \text { Dec } \\
2003\end{array}$ & $\begin{array}{l}11 \text { Jun } \\
2005\end{array}$ & 2005: 1 \\
\hline Elie dote & $\begin{array}{l}13 \text { Jun } \\
2005\end{array}$ & $\begin{array}{l}22 \text { Jan } \\
2008\end{array}$ & 2008: 1 \\
\hline
\end{tabular}

January 18,1978 , beginning of the crisis of confidence in the army and suspicion of intellectuals and even students and students, having claimed the payment of salary arrears of their parents. Central African pupils and students have been beaten. 
January 1979: in January, the Imperial Guard killed young people who protest against the high price of the uniforms imposed by Bokassa. Farmers also have been brutalized for protesting against a rise in food. One of the notorious violence during this year was about captain Alexander Banza who was mutilated before being dragged into the street and then executed.

1985: The creation of commandos or Codos opposed to the regime of Hissene Habré in the south of Chad also provoked the entry of the armed elements in CAR. Of the estimated 15,000 codos in 1985, most came to the CAR to become road cutters (zaraguinas).

1990: In the early 1990s, which was reinforced by international political and diplomatic pressure «the wind of democracy in 1990»? In this same period of social unrest. Strike that led to the death of Dr. KONJUGO.

1992: Multiparty presidential and parliamentary elections held in which Kolingba came in the last place. Because he is not confirmed into power, he cancels the results, under the pretext of irregularities that have raised tensions in the camp of the opposite party.

1996: The mutinies have raised ethnic tensions that were manifested in both the army and the civilian population, including residents in Bangui based on their region of origin. The capital was divided into two antagonistic zones. This situation lasted until the end of the munities with the signature on 25, 1997.

On 4 January 1997: in the morning, the mutineers murdered two French soldiers (an officer and a noncommissioned officer) while they were negotiating in the city (Bangui). On the night of 4 January to 5 January 1997, at 1 am, the French forces, with commandos and helicopter gunships, attack several neighborhoods of Bangui in retaliation and stop the rebellion. France begins withdrawing its forces from the republic; African peacekeepers replace French troops.

2000: December - Civil servants' stage general strike over back pay; rally organized by opposition groups who accuse President Patassé of mismanagement and corruption deteriorates into riots.

2001 May: At least 59 killed in an abortive coup attempt by former president Andre Kolingba. President Patassé suppresses the attempt with help of Libyan and Chadian troops and Congolese rebels.

2001 November - Clashes as troops try to arrest sacked army chief of staff General Francois Bozizé, accused of involvement in May's coup attempt. Thousands flee fighting between government troops and Bozizës forces.

2002 (October): After six days of fierce fighting in Bangui, the forces and troops supported by Pierre Bemba of the Democratic Republic of Congo (DRC) help to control a Loyal attempt by the army chief to dismiss General Bozizé to overthrow President Patassé. Relations with neighbors Chad, accused by Bangui of having helped Bozizé, has become worse.

2002 October. fight between Libyans and soldier loyal to dismissed army chief General Bozizé to overthrow President Patassé.

2002: The tribal management of the state initiated by Kolingba lead to the first civil war in 2002 
2003 (February): General Bozizé's troops make a significant step forward by controlling key strategic cities outside of Bangui in the northern part of CAR bringing fear and tension among the populations

2005: May 8, General Francois Bozizé is declared the winner of the presidential election with $64,6 \%$ of the vote. However, a few months later, new rebel groups are forming. First in the northwest of the country with the first attacks of the APRD (Popular Army for the Restoration of Democracy and in 2006 in the northeast with the UFDR (Union of Democratic Forces for Unity).

2006: June - UN says 33 people have been killed in a rebel attack on an army camp in the north.

2006: October - Rebels seize Birao, a town in the Northeast. President Bozizé cuts short an overseas visit.

2006: December - French fighter jets fire on rebel positions as part of the support for government troops trying to regain control of areas in the northeast.

2007: Tensions CAR's in east and north borders with Chad and Sudan worsening conflict between the two countries leading to the establishment of a detachment in Birao of European Union Force (EUFOR) in 2008 to protect civilians.

2008 January: Civil servants and teachers strike in protest over non-payment of salaries for several months.

2008 April: tensions with Paris following the nationalization of the local oil sector to the detriment of the French company Total

February - Ugandan Lord's Resistance Army rebels raid CAR.

2009 February: Ugandan LRA rebels cross into CAR.

2009, May: renewed fighting in the north between rebel forces and the army, civilians flees to South Sudan.

2009 April: Clashes between government and rebels continue. UN Security Council agrees to the creation of a new UN peace building office for CAR to address ongoing insecurity.

2010 July: rebels including members of the Patriots Convention for Justice attacked the most important city in the northeast of the Central African Republic, Birao. According to a government spokesperson, Fidèle Gouandika, 71 people were killed, including 65 in the rebel ranks.

\section{Civil war}

The Central African Republic Civil War (2004-2007) began with the rebellion by the Union of Democratic Forces for Unity (UFDR) in North-Eastern CAR, led by Michel Djotodia after François Bozizé seized power in 2003.

Source: Compiled by the authors based on information from National administrative authorities.

\subsection{Empirical model}

Based on the above statement, the following mathematical specification of the model is as follows: 
The following model is used to under the rationale behind the relationship between capital flight, hard mineral resources and political governance crisis.

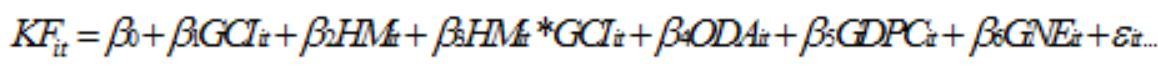

Where:

$\mathbf{K F}=$ Capital flight in million, constant $2010 \$$

GCI $=$ Normalized governance crisis index

HM $=$ Total export of diamond and Gold in million, constant $2010 \$$

$\mathbf{H M}^{*} \mathbf{G C I}=$ Association between Govemance crisis and total export of diamond and Gold in million, constant $2010 \$$

ODA $=$ Official development assistance in million, constant $2010 \$$

GDPC $=$ Growth domestic product per capita in million, constant $2010 \$$

GNE $=$ Gross national expenditures, $\%$ of GDP

To examine the role of political governance crisis in the relationship between capital flight and hard mineral resources, accent has been put on seven independents variables. Taking into the previous literature on the transmission mechanism of capital which occurs with the country, the choice of our variables is carefully done based on the previous literature and the adequacy of data to be sought.

Based on critical examination and review on capital flight, countries with an unstable political and weak institution are supported by macroeconomic and financial instability. Ramiandrisoa and Rakotomanana (2016) by undertaking a detailed review from Madagascar's political and economic history with the aim to explain the fluctuations of capital flight over 1970-2010 found that political cycles and crises are key determinants of capital flight. In similarity to this work, we expect a positive link between the interaction of hard mineral resources exports, capital flight and governance crisis in CAR as well the positive relationship between hard mineral resources exports, governance crisis, and capital flight.

In regards to official development, its links with capital flight are not conclusive. The study conducted by Gankou et al., (2016) found no significant link between capital flight and official development assistance (ODA). ODA to CAR increased by 40\% between 2005 and 2006. In 2006, it reached the US $\$ 134$ million, 9\% of gross national income, indicating a relatively low dependency of the country on ODA. Therefore, we expected a negative relationship between capital and ODA.

In regards to GDP per capita and GNE, we expected a positive link with capital due to their negative outcomes highlighted in Sect. 1. Moreover, the governance crisis and hard mineral resources have interacted in the model in order to test the hypothesis that the relationship between the amounts of hard mineral resources exports is more significant than when they are separated.

\section{Results And Discussions}


Table 2

Descritpive statistics

\begin{tabular}{|c|c|c|c|c|c|c|c|}
\hline & KF & GCI & HM & $\mathrm{HM} * \mathrm{GCl}$ & ODA & GDPC & GNE \\
\hline Mean & 62.27931 & 0.570266 & $\begin{array}{l}2.96 \mathrm{E}+ \\
08\end{array}$ & $\begin{array}{l}2.08 \mathrm{E}+ \\
08\end{array}$ & $\begin{array}{l}1.92 E+ \\
08\end{array}$ & 453.2353 & 110.5663 \\
\hline Median & 59.90000 & 0.512571 & $\begin{array}{l}1.75 \mathrm{E}+ \\
08\end{array}$ & 58896732 & $\begin{array}{l}2.08 \mathrm{E}+ \\
08\end{array}$ & 431.4989 & 106.0340 \\
\hline Maximum & 288.9000 & 1.000000 & $\begin{array}{l}9.26 \mathrm{E}+ \\
08\end{array}$ & $\begin{array}{l}9.26 \mathrm{E}+ \\
08\end{array}$ & $\begin{array}{l}3.31 E+ \\
08\end{array}$ & 545.5199 & 148.6488 \\
\hline Minimum & -91.00000 & 0.000000 & 9506.286 & 0.000000 & 59570000 & 397.8115 & 95.60713 \\
\hline Std. Dev. & 89.14983 & 0.437441 & $\begin{array}{l}2.85 \mathrm{E}+ \\
08\end{array}$ & $\begin{array}{l}2.73 E+ \\
08\end{array}$ & 73137106 & 48.03998 & 12.15345 \\
\hline Skewness & 0.604156 & -0.277677 & 0.832201 & 1.167237 & -0.026372 & 0.725777 & 1.864557 \\
\hline Kurtosis & 3.213350 & 1.409533 & 2.280948 & 3.088671 & 2.120286 & 2.004124 & 6.059459 \\
\hline Jarque-Bera & 1.819188 & 3.429253 & 3.972119 & 6.594635 & 0.938486 & 3.744353 & 28.11378 \\
\hline Probability & 0.402688 & 0.180031 & 0.137235 & 0.036982 & 0.625475 & 0.153789 & 0.000001 \\
\hline Sum & 1806.100 & 16.53771 & $\begin{array}{l}8.57 \mathrm{E}+ \\
09\end{array}$ & $\begin{array}{l}6.02 E+ \\
09\end{array}$ & $\begin{array}{l}5.55 E+ \\
09\end{array}$ & 13143.82 & 3206.422 \\
\hline $\begin{array}{l}\text { Sum Sq. } \\
\text { Dev. }\end{array}$ & 222535.4 & 5.357924 & $\begin{array}{l}2.28 \mathrm{E}+ \\
18\end{array}$ & $\begin{array}{l}2.09 \mathrm{E}+ \\
18\end{array}$ & $\begin{array}{l}1.50 \mathrm{E}+ \\
17\end{array}$ & 64619.52 & 4135.775 \\
\hline Observations & 29 & 29 & 29 & 29 & 29 & 29 & 29 \\
\hline
\end{tabular}

Author's construction

The Table 2 presents the summary statistics for all variables used in this study over the period of 1978-2010 in CAR. For instance, the mean of $\mathrm{KF}$ for the sample is 62.27931 per year, with a standard deviation of 89.14983, which varies significantly. Hard mineral exports have a minimum of 9506.286 and a maximum of $9.26 \mathrm{E}+08$. The average is $2.96 \mathrm{E}+08$ and the standard deviation is $2.85 \mathrm{E}+08$, which is large, meaning it exhibit more dispersion from the mean. The interaction between governance crisis and hard mineral resources has the lowest value of 0.000000 and the highest value of $9.26 \mathrm{E}+08$. It has an average of $2.08 \mathrm{E}+08$ and the standard deviation is $2.73 \mathrm{E}+08$ which exceed the mean, hence it exhibit from the mean. Moreover, the Kurtosis values and Jarque- Bera test statistics indicate our variables are normally distributed and positively skewed. 
Table 3

Augmented Dickey-Fuller, Philip-Perron

\begin{tabular}{|c|c|c|}
\hline Variables & ADF statistic & PP statistic \\
\hline $\mathrm{KFt}$ & 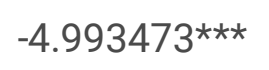 & $-5.006754^{\star \star \star}$ \\
\hline$\Delta \mathrm{KFt}$ & $-6.777601 * \star \star$ & $-17.69915^{\star \star \star}$ \\
\hline GClt & $-4.16228^{* \star}$ & $-4.162228^{\star \star}$ \\
\hline$\Delta \mathrm{GClt}$ & $-5.237212^{\star \star \star}$ & $-13.17257^{\star \star \star \star}$ \\
\hline HMt & $-2.971489 * *$ & $-2.894411^{\star \star}$ \\
\hline$\Delta \mathrm{HMt}$ & $-9.527998 * \star \star$ & $-10.82558^{\star \star *}$ \\
\hline $\mathrm{HMt} * \mathrm{GClt}$ & $-3.814241^{\star}$ & $-3.820849 *$ \\
\hline$\Delta \mathrm{HMIt}^{\star} \Delta \mathrm{GClt}$ & $-4.123817 * \star$ & $-17.76611^{\star \star \star}$ \\
\hline ODAt & -1.781877 & -1.818200 \\
\hline$\triangle \mathrm{ODAt}$ & $-6.995991 * \star \star$ & 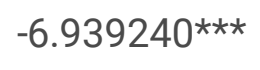 \\
\hline GDPCt & $-3.113456^{\star \star}$ & $-3.113456^{\star \star}$ \\
\hline$\triangle \mathrm{GDPCt}$ & $-6.487662^{\star \star \star}$ & $-6.549853^{\star \star \star}$ \\
\hline GNEt & $-3.735682^{\star \star}$ & $-3.735682^{\star \star}$ \\
\hline$\triangle \mathrm{GNEt}$ & $-4.170631^{\star \star}$ & $-9.490669 \star \star \star *$ \\
\hline
\end{tabular}

Before conducting the regression model, it is necessary to check whether our variables are stationary. Moreover, The ARDL method is only applicable for times series which are combination of I (0) and I (1) variables. Thus, the test of stationarity is an imperative step in our empirical analysis. ADF and PP unit roots are applied to confirm whether our variables have unit root problem. As can be observed in the Table 3, the results of $A D F$ at the first level are mixed. ADF tests statistics accepted the unit-root null hypothesis against the stationarity only for ODA. However, in the first differences, all the times series rejected the unit root null hypothesis at 1,5 , and $10 \%$ significance levels, which means there is homoscedasticity. The non-presence of stationarity allows us to examine the long run relationship between capital flight and Hard mineral resources by using ARDL approach to cointegration. 
Table 4

Lag length selection order criteria

\begin{tabular}{|lllllll|}
\hline Lag & LogL & LR & FPE & AIC & SC & HQ \\
\hline 0 & -2009.747 & NA & $\begin{array}{l}1.78 \mathrm{e}+ \\
56\end{array}$ & 149.3887 & 149.7246 & 149.4886 \\
\hline 1 & -1924.467 & $120.0244^{*}$ & $\begin{array}{l}1.38 \mathrm{e}+ \\
55^{*}\end{array}$ & $146.7012^{\star}$ & $149.3889^{*}$ & $147.5004^{*}$ \\
\hline Endogenous: KFt; GClt; HM, HM*GClt; ODAt. GDPCt; GNEt; Exogenous: constant \\
\hline *Lag selection by the criteria \\
\hline \multicolumn{4}{|l}{ Source: generated from Eview 9.5 } \\
\hline
\end{tabular}

Before apply the bounds test cointegration and select the suitable ARDL model, Akaike information criterion (AIC) is applied to choose the adequate optimal lag. The criterion for variables lag order section is presented in the Table 4. By minimizing the AIC value, it can be observed that the maximum of lags is set to 1 .

Table 5

Bounds test cointegration

\begin{tabular}{|lll|}
\hline Test Statistic & Value & \multicolumn{1}{l|}{ K } \\
\hline F-statistic & 5.362407 & 6 \\
\hline \multicolumn{2}{|l|}{ Critical Value } & Bounds \\
\hline Significance & I0 Bound & I1 Bound \\
\hline $10 \%$ & 1.99 & 2.94 \\
\hline $5 \%$ & 2.27 & 3.28 \\
\hline $2.5 \%$ & 2.55 & 3.61 \\
\hline $1 \%$ & 2.88 & 3.99 \\
\hline
\end{tabular}

Author's construction

In the light of the evidence of the times series being either stationary at level of first difference, we conduct bounds test for cointegration for our best model. The results of bounds tests are reported in Table 5. The results show that the null hypothesis of no long run relationship can be rejected at $10 \%, 5 \%, 2.5 \%$ and $1 \%$, demonstrating by the estimated F-statistics (5.362407) that exceed the upper critical bound at different significance level. Hence, we can reject the null hypothesis of no long-run relationship in our ARDL model; therefore conclude that there is a long run equilibrium relationship between capital flight and hard mineral resources in Central African Republic. Furthermore, the existence of cointegration relationship in ARDL model suggests that further analysis is necessary for this model. 
Table 6

short and long run estimates

\begin{tabular}{|c|c|c|c|c|}
\hline \multicolumn{5}{|l|}{ Short run } \\
\hline Variable & Coefficient & Std. Error & t-Statistic & Prob. \\
\hline $\mathrm{D}(\mathrm{GCl})$ & -14.362882 & 35.265707 & -0.407276 & 0.6884 \\
\hline $\mathrm{D}(\mathrm{HM})$ & -0.000000 & 0.000000 & -0.416232 & 0.6819 \\
\hline $\mathrm{D}\left(\mathrm{HM}{ }^{*} \mathrm{GCl}\right)$ & 0.000000 & 0.000000 & 2.076630 & 0.0516 ** \\
\hline $\mathrm{D}(\mathrm{ODA})$ & -0.000001 & 0.000000 & -3.055857 & $0.0065^{\star \star}$ \\
\hline $\mathrm{D}(\mathrm{GDPC})$ & 1.998162 & 0.807895 & 2.473296 & $0.0230 * \star$ \\
\hline $\mathrm{D}(\mathrm{GNE})$ & -8.412649 & 1.153659 & -7.292143 & $0.0000 * \star *$ \\
\hline CointEq (-1) & -1.438624 & 0.180654 & -7.963420 & $0.0000 * \star \star$ \\
\hline \multicolumn{5}{|c|}{ 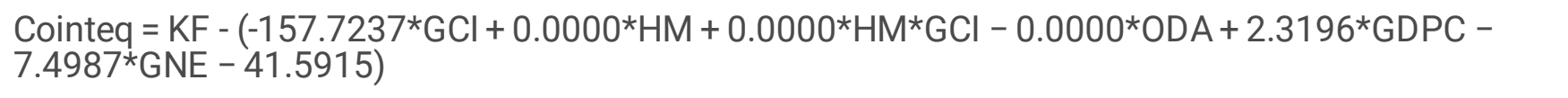 } \\
\hline \multicolumn{5}{|l|}{ Long Run } \\
\hline Variable & Coefficient & Std. Error & t-Statistic & Prob. \\
\hline $\mathrm{GCl}$ & -157.723653 & 81.196214 & -1.942500 & $0.0670 *$ \\
\hline $\mathrm{HM}$ & 0.000000 & 0.000000 & 0.280662 & 0.7820 \\
\hline $\mathrm{HM}^{*} \mathrm{GCl}$ & 0.000000 & 0.000000 & 2.853261 & $0.0102^{\star \star \star}$ \\
\hline ODA & -0.000001 & 0.000000 & -1.921007 & $0.0699 *$ \\
\hline GDPC & 2.319555 & 0.681943 & 3.401390 & $0.0030 * \star \star$ \\
\hline GNE & -7.498683 & 2.627586 & -2.853830 & $0.0102^{\star \star \star}$ \\
\hline
\end{tabular}

The results of short run and long run estimates are reported in Table 6 using the ARDL approach. Beginning with the long run analysis, the results show a negative and significance impact of governance crisis, official development assistance and gross national expenditure on capital flight. This negative and insignificant link could be explained by the fact capital flight could be high before violent regimes changes and low in the subsequent period (Geda and Yimer, 2016) as well as by a prompt policy putting in place such as embargo in hard mineral sector. Moreover, this negative and insignificant link could be explained by urgent measures, which have been put in place to solve for instance coup d'états or munities occurred in the country. The result for instance of gross national expenditures is not consistent with the findings of Agu (2010) which show that government expenditure had a direct impact on capital flight. In terms of capital flight and official development assistance, the negative link found do not support the work of Gankou et al., 2016, which find no significant link between capital flight and official development assistance. 
The interaction between hard mineral resources and governance crisis, GDP per capita have a positive and a significance effect on capital flight. This positive link could be explained by the duration of the governance crisis. Once, for example, such as features are associated with poor regulation in the hard market, political uncertainty and crime, investors are likely to move their resources to less risky environment. The finding is in line with the work of Ndiaye and Siri (2016) who found a positive link between capital flight and natural resources as well as the study of Mpenya et al., 2016. A hard mineral resources export exhibits a positive but insignificant effect on capital flight.

In the short-run analysis, the results show that official development assistance, gross national expenditures have a negative and a significant impact at $5 \%$ and $1 \%$ significance level on capital flight. Specifically, a onedollar increase in official development assistance and gross national expenditures decrease the capital flight by $-3.05,-7.29$ dollar respectively. The interaction of hard mineral resources and governance crisis and GDP per capita has a positive and a significant effect at $5 \%$ levels of significance. The relationship is such that a one dollar increases in interaction between governance crisis and hard mineral resources and GDP per capita leads to 2.07, 2.04-dollar increase in capital flight.

Governance crisis and hard mineral resources have a negative but insignificant impact on capital flight. The error correction model which shows the speed adjustment parameter and determines the pace of adaptation towards the long-term equilibrium is negative and significant but does not comprise between 0 and - 1 for our model. This suggests that the discrepancies between shocks and the trend are reduced in less than one year. In such cases, equilibrium is achieved by fluctuations of capital flight, with the amplitude getting smaller until the final extinction of the shock (Narayan and Smith, 2006).

To ensure the goodness of fit of model, the diagnostic and stability tests are performed. For the diagnostic test, Jarque-Bera test for normality and the Breush-Godrey test for serial correlation, Breusch-Pagan-Godfrey for heteroskedasticity have been examined. For the stability tests, Cumulative (CUSUM) and cumulative sum of squares (CUSUMsq) have been conducted for goodness of fit. The results in Table 6 show that our model has no serial correlation, normally distributed and free from heteroskedasticity. Moreover, the result of the stability test show that the plots of CUSUM and CUSUMsq fall with the critical bounds of $5 \%$ level of significance. This implies that, our model is well specified and stable over the period of 1978-2010

Table 6

Diagnostic test

\begin{tabular}{|lll|}
\hline Diagnostic & Statistic & Conclusion \\
\hline $\begin{array}{l}\text { Heteroskedasticity Breusch-Pagan- } \\
\text { Godfrey }\end{array}$ & $\begin{array}{l}\text { Chi-Square }(9) \\
0.433075(0.9005)\end{array}$ & There is no heteroskedasticity \\
\hline Normality test & $\begin{array}{l}\text { Jarque-Bera Test }=1.860271 \\
\text { P-value }=0.394500\end{array}$ & $\begin{array}{l}\text { Residual are normally } \\
\text { distributed }\end{array}$ \\
$\begin{array}{l}\text { Breusch-Godfrey Serial Correlation LM } \\
\text { Test }\end{array}$ & $\begin{array}{l}\text { Chisquare }(3) \\
1.424758(0.2481)\end{array}$ & No serial correlation \\
\hline Source: author's construction & & \\
\hline
\end{tabular}




\section{Conclusion}

This study has examined the relationship between capital flight, hard mineral resources exports and capital flight in Central African Republic for the 1978-2010, focusing governance crisis index constructed on detailed review of the country's governments and constitution changes, Tensions, violence and protest politically motivated as well as politico-military crises.

The ARDL approach to cointegration is applied to identify long run and short run dynamics between selected variables. The results of short and long run show that the association of hard mineral resources and governance crisis have a positive and a significant relationship at $5 \%$ levels of significance while the rest of variables under our investigated have a mixed relationship in short and long run with capital flight in CAR.

Considering this significant level of capital flight, hard mineral resources and governance crisis, this paper has several policy implications. First, the country needs a rigorous reform in security sector and democratic governance in order to have an effective centralized, hierarchical, coercive government. Second, support peace and reconciliation by strengthening the performance of the security and justice sectors, and improving democratic governance and electoral processes. Third, there is evidence of hard mineral resources fueled capital flight in CAR, therefore there is a need to put in place a consensual and incentive management rules to promote transparency in the management of hard mineral resources in CAR. Moreover, there is a need to strengthen the human and material capacities of public bodies in charge of the management of the sector (General directorate of mines, Kimberley process, the Special Anti-Fraud Unit (USAF) to avoid corruption and trade misinvoicing considered as determinants of capital flight.

\section{References}

Agu, C. (2010). Domestic Macroeconomic Policies and Capital Flight from Nigeria: Evidence from a Macroeconometric Model. Central bank of Nigeria, 48(3), 49.

Arezki, M. R., \& van der Ploeg, F. (2007). Can the Natural Resource Curse Be Turned Into a Blessing? The Role of Trade Policies and Institutions (EPub) (No. 7-55). International Monetary Fund.

Asongu, S. A., \& Nwachukwu, J. C. (2017). Fighting capital flight in Africa: evidence from bundling and unbundling governance. Journal of Industry, Competition, and Trade, 17(3), 305-323.

Asongu, S. A., \& Odhiambo, N. M. (2019). Governance, capital flight, and industrialization in Africa. Journal of Economic Structures, 8(1), 36.

Aspinall, E. (2007). The construction of grievance. Journal of Conflict Resolution, 51(6), 950-972.

Auty, R. (2004). Natural resources and civil strife: a two-stage process. Geopolitics, 9(1), 29-49.

Boyce, J. K., \& Ndikumana, L. (2012), 'Capital Flight from Sub-Saharan African Countries': Updated Estimates, 1970-2010. Polit. Econ. Res. Inst. Inst. Res. Rep., no. 
Bredino, \& Sonin, K. (2009). Why resource-poor dictators allow freer media: A theory and evidence from panel data. American political science Review, 103(4), 645-668.

Fofack, H., \& Ndikumana, L. (2009). Potential gains from capital flight repatriation for sub-Saharan African countries. The World Bank.

Fofack, H., \& Ndikumana, L. (2010). Capital flight repatriation: Investigation of its potential gains for subSaharan African countries. African Development Review, 22(1), 4-22.

Gankou, J. M., Bendoma, M., \& Sow, M. N. (2016). The institutional environment and the link between capital flows and capital flight in Cameroon. African Development Review, 28(S1), 65-87S.

Fiderikumo, P., \& Adesuji, A. (2018). Impact of Capital Flight on Economic Growth in Nigeria: An Econometric Approach. Journal of Business and Economic Development, 3(1), 22.

Demachi, K. (2013). Capital Flight and Transfer from Resource-Rich Developing Countries.

Egorov, G., Guriev, S.,

Geda, A., \& Yimer, A. (2016). Capital flight and its determinants: the case of Ethiopia. African Development Review, 28(S1), 39-49.

Kangoye, T. (2013). Does aid unpredictability weaken governance? Evidence from developing countries. The Developing Economies, 51(2), 121-144.

Khan, M., \& Sajjid, M. Z. (2005). The Exchange Rates and Monetary Dynamics in Pakistan: An Autoregressive Distributed Lag (ARDL) Approach. Lahore Journal of Economics, 10(2), 87-99.

Kolstad, I. (2009). The resource curse: Which institutions matter? Applied Economics Letters, 16(4), $439-442$.

Kwaramba, M., Mahonye, N., \& Mandishara, L. (2016). Capital flight and trade misinvoicing in Zimbabwe. African Development Review, 28(S1), 50-64.

Le Billon, P. (2011), Extractive sectors and illicit financial flows: What role for revenue governance initiatives. U4 Issue.

Le, Q. V., and Zak, P. J. (2006). Political risk and capital flight. Journal of International Money and Finance, 25(2), 308-329.

Lensink, R., Hermes, N., \& Murinde, V. (2000). Capital flight and political risk. Journal of International Money and Finance, 19(1), 73-92.

Ljungberg, D., and Friedl, C. (2014). Does Natural Resource Abundance Cause Capital Flight. Stockholm: Stockholm School of Economics, unpublished.

Mpenya, H. T., Metseyem, C., \& Epo, B. N. (2016). Natural resources and capital flight in Cameroon. African Development Review, Vol 28, No. 1, pp. 88-99. 
Musila, J. W., \& Sigué, S. P. (2010). Corruption and international trade: An empirical investigation of African countries. World Economy, 33(1), 129-146.

Narayan, P.K. \& Narayan, S. (2006), "Savings behaviour in Fiji: an empirical assessment using the ARDL approach to cointegration", International Journal of Social Economics, 33(7), 468-480.

Ndiaye, A. S., \& Siri, A. (2016). Capital flight from Burkina Faso: drivers and impact on tax revenue. African Development Review, 28(S1), 100-112.

Ndikumana, L. (2016). Causes and effects of capital flight from Africa: lessons from case studies. African Development Review, 28(S1), 2-7.

Ndikumana, L. and Boyce, J. K. (2003). Public debts and private assets: explaining capital flight from SubSaharan African countries. World Development, Vol 31, No. 1, 107-130.

Ndikumana, L., \& Sarr, M. (2019). Capital flight, foreign direct investment and natural resources in Africa. Resources Policy, 63, 101427.

Nkurunziza, J. D. (2014). Capital Flight and Poverty Reduction in Africa. Capital Flight from Africa: Causes, Effects, and Policy Issues, 81.

Nkurunziza, J. D. (2015), 'Capital Flight and Poverty Reduction in Africa', in I. Ajayi and L. Ndikumana (eds.), Capital Flight from Africa: Causes, Effects and Policy Issues (pp. 81-110), Oxford University Press, Oxford.

Ondo, A \& Taylor, Z. (2012), Oil Rents and Capital Flight: How Oil Rents Affect Capital Flight in Sub-Saharan Africa, Applied Statistics for the Biological and Physical SciencesSTT212.

Ong'ayo, A. O. (2008). Political instability in Africa: Where the problem lies and alternative perspectives. Amsterdam: The African Diaspora Policy Centre. Under: www. Diaspora Centre. Org/DOCS/Political_Instabil. pdf (accessed October 15, 2009).

Pesaran, M. H., Shin, Y., \& Smith, R. P. (1999). Pooled mean group estimation of dynamic heterogeneous panels. Journal of the American statistical Association, 94(446), 621-634.

Pesaran, M. H., Shin, Y., \& Smith, R. J. (2001). Bounds testing approaches to the analysis of level relationships. Journal of applied econometrics, 16(3), 289-326.

Polterovich, V., Popov, V., \& Tonis, A. (2007). Resource abundance, political corruption, and instability of democracy. Political Corruption, and Instability of Democracy.

Ramiandrisoa, O. T., \& Rakotomanana, E. J. M. (2016). Why is there a capital flight from developing countries? The case of Madagascar. African Development Review, 28(S1), 22-38.

Ross, M. L. (2013). The politics of the resource curse: a review. Handbook on the Politics of Development.

Valenzuela, J. R. (2020), Natural Resource Governance, Grievances and Conflict, Springer Fachmedien Wiesbaden, available at https://www.springerprofessional.de/en/natural-resource-governance-grievances-and- 
Vogel, C. \& Havenith, J. (2014), beyond greed or grievance: understanding conflict in resource-rich states, African Arguments, available at https://africanarguments.org/2014/04/17/beyond-greed-or-grievanceunderstanding-conflict-in-resource-rich-states-by-christoph-vogel-and-joschka-havenith/

Wantchekon, L. (2002). Why do resource dependent countries have authoritarian governments?. Journal of African Finance and Economic Development, 5(2), 57-77.

Williams, A., \& Le Billon, P. (Eds.). (2017). Corruption, natural resources and development: From resource curse to political ecology. Edward Elgar Publishing.

Yapatake Kossele, T. P., \& Mbai-Akem, M. G. N. (2019). Capital flight and extent of corruption control in the least corrupt African countries. Indian Growth and Development Review, ahead-of-print. Ahead-of-print.

Yapatake Kossele TP, Njong MA. Capital flight and diamond exports in the Central African Republic: The role of political governance crisis. Afr Dev Rev. 2020; 1-13. https://doi.org/10.1111/1467-8268.12445

\section{Figures}

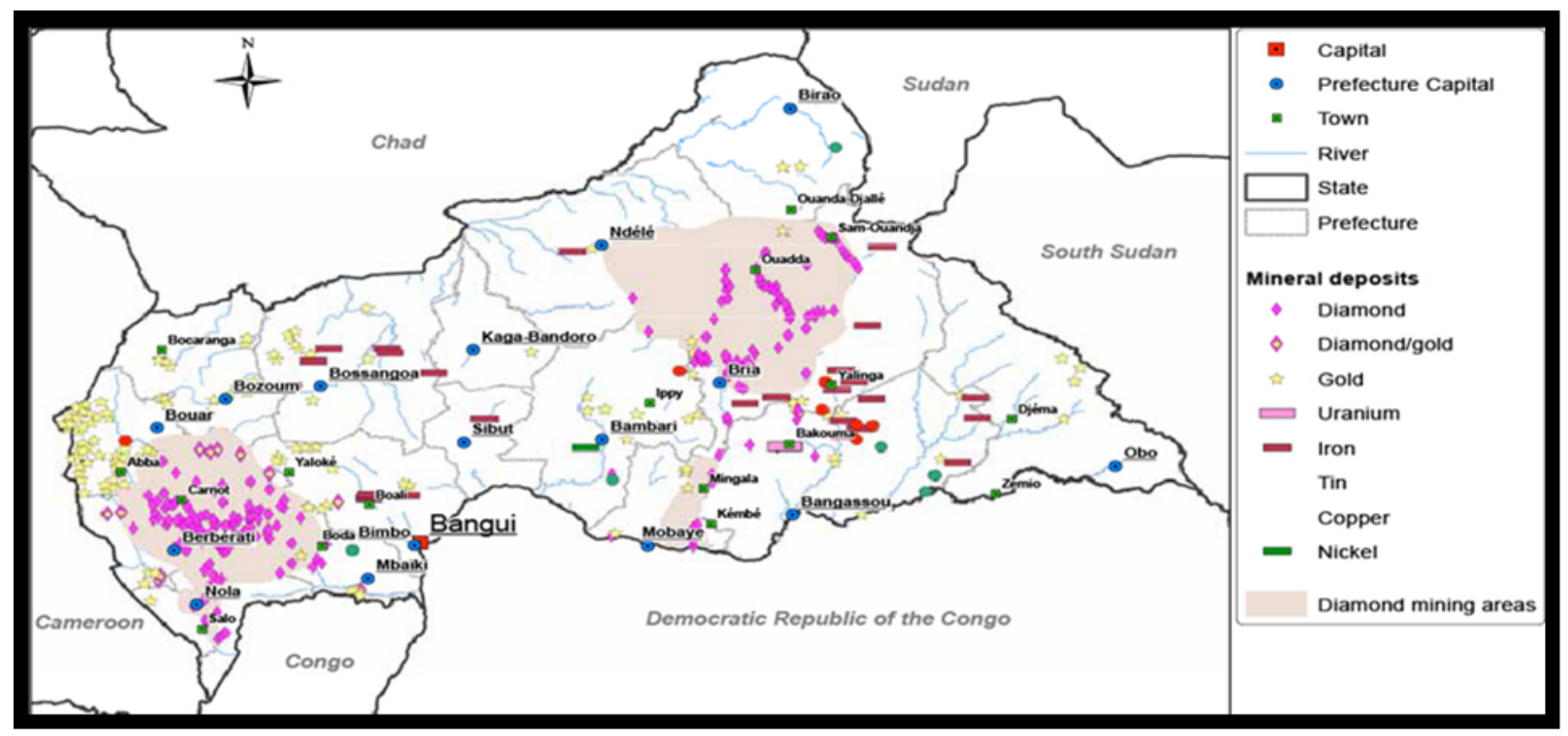

Source: International Peace Information Security (IPIS), 2012

\section{Figure 1}

Distribution of hard mineral resources in the different regions of the Central African Republic. 


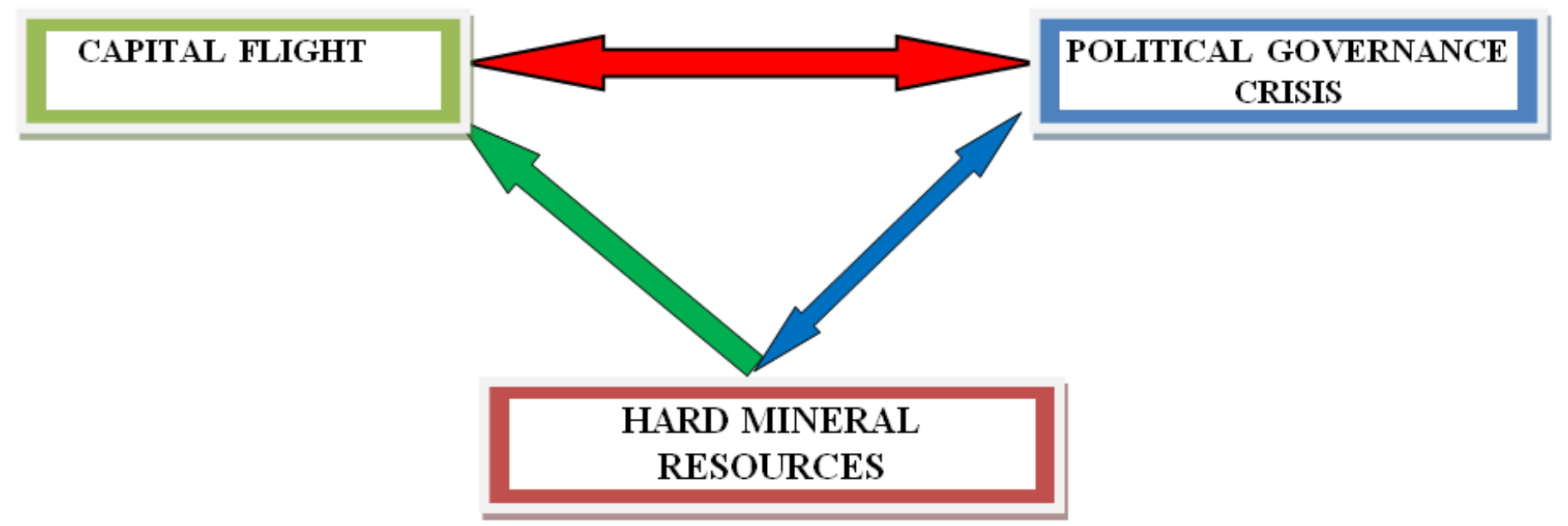

Source: Author's construction

Figure 2

linkages between capital flight, diamond exports, and political governance Crisis in the CAR

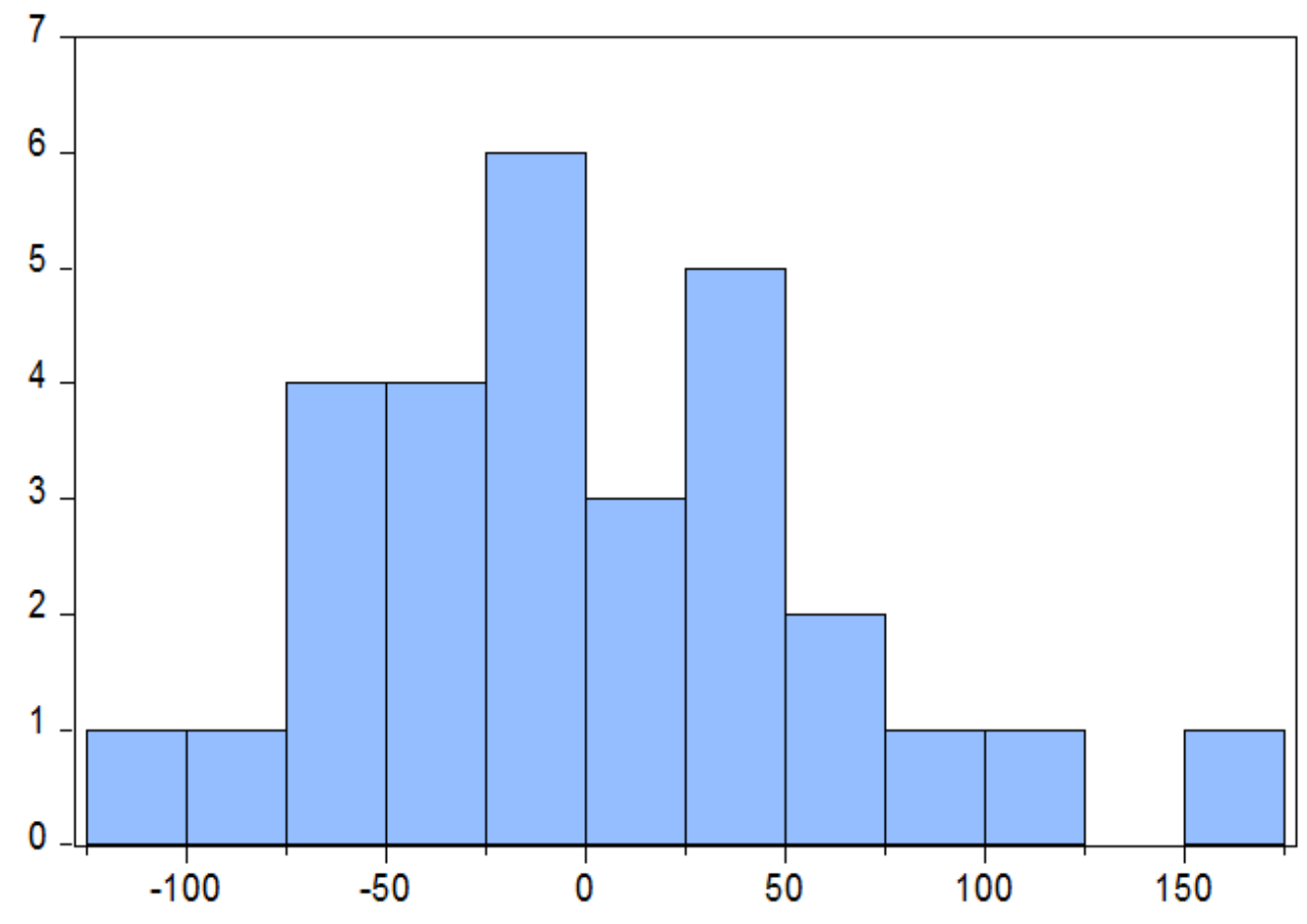

\begin{tabular}{|c|c|}
\hline \multicolumn{2}{|c|}{$\begin{array}{l}\text { Series: Residuals } \\
\text { Sample } 19802010 \\
\text { Observations } 29\end{array}$} \\
\hline Mean & $4.89 \mathrm{e}-14$ \\
\hline Median & -2.507064 \\
\hline Maximum & 160.4425 \\
\hline Minimum & -105.3823 \\
\hline Std. Dev. & 59.20511 \\
\hline Skewness & 0.587944 \\
\hline Kurtosis & 3.396005 \\
\hline Jarque-Bera & 1.860271 \\
\hline Probability & 0.394500 \\
\hline
\end{tabular}

Author's construction: Eviews 9.5

Figure 3

Normality test 


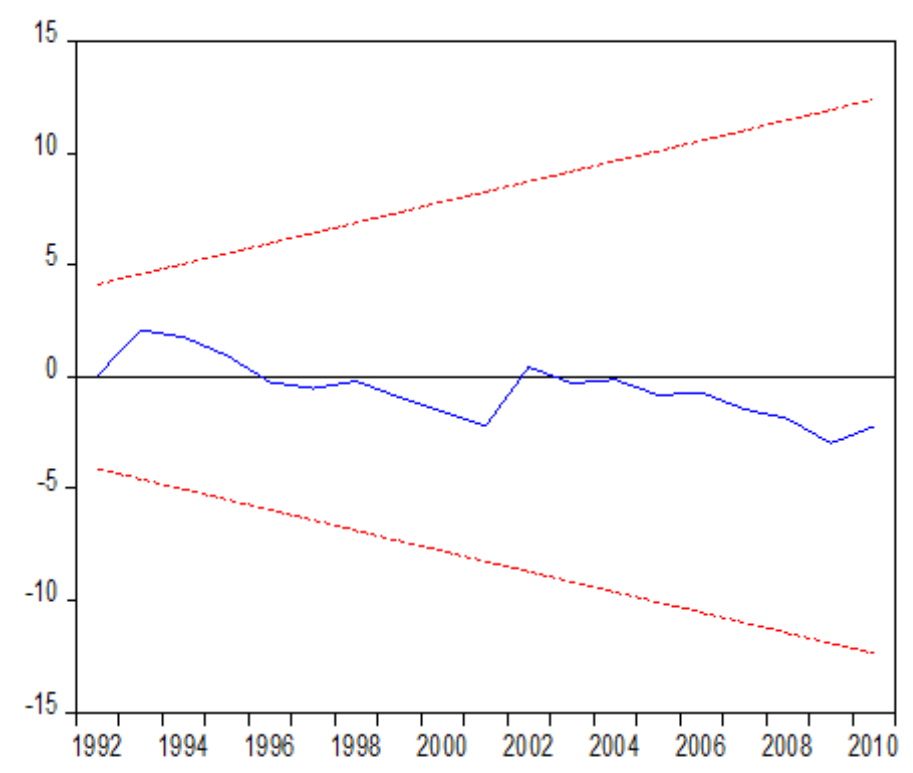

CUSUII -.... 5\% Significance

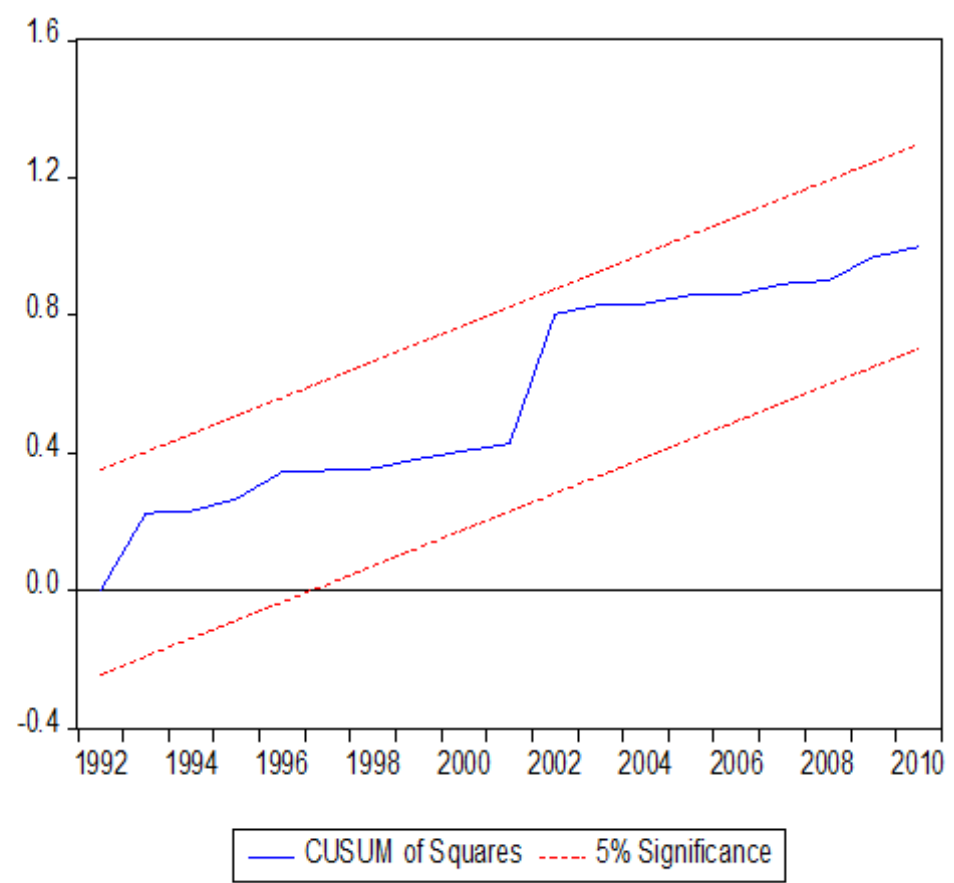

Figure 4

Model stability test of cumulative sum residuals and Model stability test of cumulative sum of Squares residuals

\section{Supplementary Files}

This is a list of supplementary files associated with this preprint. Click to download.

- SUPPLEMENTARIESFILES2020.doc 